\title{
Communication of Opinion leader in Commodifying Contract Marriage in Siri Marriage Village in Pasuruan
}

\section{Komunikasi Opinion leader dalam Komodifikasi Kawin Kontrak Di Kampung Nikah Siri di Pasuruan}

\author{
Didik Hariyanto $^{1 *}$, Maulia Figo Arian Difa ${ }^{2}$ \\ 1,2 Program Studi Ilmu Komunikasi, Fakultas Bisnis, Hukum, dan Ilmu Sosial, Universitas Muhammadiyah Sidoarjo \\ Jl. Mojopahit No. 666B, Sidowayah, Celep, Sidoarjo, Jawa Timur
}

OPEN ACCESS

ISSN 2541-2841 (online) ISSN 2302-6790 (print)

Edited by: Nur Maghfirah A.

${ }^{*}$ Correspondence: Ddidik Hariyanto didikhariyanto@umsid a.ac.id

Citation:

Hariyanto, Didik and Diva,

Maulia, F. A. D (2021)

Komunikasi Opinion leader dalam Komodifikasi Kawin Kontrak di Kampung Nikah Sirih

di Pasuruan, Kanal, 9(3).

Doi:10.21070/kanal.v9i3.1574

\begin{abstract}
This study aims to analyze how the communication used by opinion leaders in Kalisat village gives rise to a form of commodification of contract marriage. The method in this research is using a qualitative descriptive method. Data collection was carried out by direct field observation in which researchers went directly to the field to find data in the field and carried out in-depth interview techniques that were carried out freely. The results of this study are, in the commodification process of this contract marriage there is a form of communication in which this communication is carried out face to face or face to face, namely a communication process carried out by the communicator to a communicant which is carried out directly without any help or intermediary of a media. The communication technique used by opinion leaders to invite and convince prospective brides and grooms, both men and women, is to use persuasive communication techniques. Where opinion leaders try to persuade and promise a number of advantages if they want to follow this practice, this is in accordance with the basic principles of commodification theory which changes something that initially only has use value and then turns it into something that can be sold and has a selling value in the market.

Keywords: Opinion leader Communication; Commodification; Contract Marriage.
\end{abstract}

\begin{abstract}
Abstrak
Penelitian ini bertujuan untuk menganalisa bagaimana komunikasi yang di gunakan para opinion leader di desa Kalisat sehingga menimbulkan suatu bentuk komodifikasi kawin kontrak. Metode dalam penelitian ini yaitu menggunakan metode deskriptif kualitatif. Pengumpulan data dilakukan dengan observasi lapangan langsung yang mana peneliti terjun langsung ke lapangan untuk mencari data di lapangan serta melakukan teknik wawancara mendalam yag dilakukan secara bebas. Hasil penelitian ini adalah, dalam proses komodifikasi kawin kontrak ini terdapat suatu bentuk komunikasi yang mana komunikasi ini dilakukan secara tatap muka atau face to face yakni suatu proses komunikasi yang dilakukan oleh komunikator kepada seo-
\end{abstract}


rang komunikan yang dilakukan secara langsung tanpa adanya bantuan atau perantara sebuah media. Tekhnik komuikasi yang digunakan para opinion leader guna mengajak serta meyakinkan calon mempelai baik pria maupun wanita yaitu menggunakan tekhnik komunikasi persuasif. Yang mana para opinion leader berusaha untuk membujuk dan menjajikan sejumlah keuntungan apabila mereka mau mengikuti praktik ini hal ini sesuai dengan prinsip dasar teori komodifikasi yang mana merubah sesuatu barang yang awalnya hanya mempunyai nilai guna lalu di rubah menjadi sesuatu yang bisa dijual dan mempunyai nilai jual di pasar.

Kata Kunci: Komunikasi Pemimpin Opini; Komodifikasi; Kawin Kontrak.

\section{PENDAHULUAN}

Fenomena kawin kontrak di Indonesia sudah ada sejak akhir 1980an di kawasan puncak, Bogor. Yang mana para pelakunya yaitu orang arab dengan wanita setempat. Biasanya identitas para wanita hingga keluarganya dipalsukan, setelah itu calon mempelai diarahkan ke penghulu, tanpa adanya lamaran. Pelaksaan kawin kontrak ini di laksanakan di kediaman pelaku wanita, yang dihadiri wali, saksi dan penghulu. Serta biasanaya identitas para wali, saksi dan penghulunya juga dipalsukan.

Kawin kontrak atau biasa di sebut juga nikah mut'ah dalam bahasa Arab yaitu kondisi dimana seorang pria yang mempersunting seorang wanita tertentu disertai dengan sejumlah harta dalam jumlah yang sebelumnya sudah ditentukan serta dalam jangka waktu yang tertentu sesuai kesepakatan kedua belah pihak. Fenomena yang terjadi di Pasuruan, wanita pelaku kawin kontrak dipatok harga oleh para makelarnya dengan mahar mulai dari 15 juta rupiah (untuk yang sudah janda/sudah pernah menikah) hingga 35 juta rupiah (untuk yang masih perawan/belum pernah menikah). Kawin kontrak di Desa Kalisat, menjadi fenomena yang biasa dan sudah banyak ditemukan di desa ini. Tingginya jumlah praktik kawin kontrak di Desa Kalisat ini, para pelaku wanita di Desa Kalisat dapat melakukan praktik terlarang ini berulang kali, bahkan bisa sampai lebih dari 4 kali. Waktu yang ditentukan dalam kawin kontrak ini pun tidak bisa dipastikan, hanya saja dapat ditentukan atas dasar persetujuan kedua belah pihak.

Pada jaman Nabi SAW, dalam Islam kawin kontrak pernah diizinkan saat para sahabat terjadi peperangan yang mana pada waktu itu para sahabat dalam kondisi membujang dan meninggalkan isteri mereka, karna untuk menghindari penyimpangan sosial, akan tetapi pada saat Rasulullah SAW berhasil membebaskan kota mekkah pada tahun 8 Hijriah/630 Masehi, Rasulullah mulai mengharmakan kawin kontrak. Hal ini dijelaskan dalam Hadist Riwayat Muslim no. 1406 yang artinya "Rasulullah shallallaahu 'alaihi Wa Sallam pernah memerintahkan kami guna melakukan nikah mut'ah ini pada saat sedang melaksanakan Fathul Makkah ketika memasuki kota Makkah kemudian sebelum kami meninggalkan kota Makkah, beliau pun telah melarang kami dari bentuk nikah tersebut." (HR. Muslim No. 1406).

Selain hukum agama, hukum negara juga melarang adanya praktik kawin kontrak. Seperti yang sudah di atur da- lam undang-undang Nomer 1 Tahun 1974 perihal perkawinan. Dalam undang-undang perkawinan ini terdapat dua pasal yang mengatur tentang perkawinan pasal 1 yang menyebutkan bahwa perkawinan ialah suatu ikatan lahir batin antara seorang pria dengan seorang wanita sebagai ikatan suami isteri yang bertujuan guna menjalin bahtera rumah tangga (membentuk keluarga) yang bahagia dan kekal berdasarkan Ketuhanan Yang Maha Esa. Sedangkan pasal 2 menjelaskan bahwa perkawinan ialah dianggap sah apabila dilaksanakan menurut hukum yang berlaku di dalam hukum masing-masing agama dan kepercayaanya itu. Jadi bisa disimpulkan kawin kontrak di mata hukum negara tidak sah karna tidak berdasarkan pada agama dan kepercayaannya.

Faktor utama bagi sebagian pelaku kawin kontrak di desa Kalisat adalah karna kondisi sosial ekonomi yang rendah, status janda, usia, serta faktor pendidikan, faktor keluarga juga memengaruhi bagi para pelaku kawin kontrak wanita. Sedangkan pelaku pria alasan mereka yaitu guna ingin memenuhi kebutuhan seksual, status duda, serta niat dan kemauan untuk berpoligami karna atas dasar kemauannya sendiri. Serta karna syarat yang mudah dan tidak rumit untuk kawin kontrak juga menjadi faktor pendukung (Fitriyani \& Fajriyah, 2015).

Selain karna faktor di atas, adanya peran komunikasi para opinion leader pun berpengaruh dalam keberlangsungan praktik terlarang ini, khususnya di Desa Kalisat, Kecamatan Rembang, Pasuruan. Hal ini dapat dilihat dari cara komunikasi dari para opinion leader guna mengajak dan meyakinkan calon pelaku kawin kontrak untuk memantapkan diri serta tidak ragu untuk ikut terjun dalam praktik ini, dengan dijanjikan beberapa keuntungan didalamnya. Komunikasi yaitu interaksi yang dilakukan oleh dua orang atau lebih yang mempunyai tujuan yang sama, yaitu saling bertukar informasi. Komunikasi menurut Shannon dan Weaver (1949) yaitu suatu bentuk kegiatan interaksi yang digunakan oleh manusia yang saling mempengaruhi manusia lainnya, serta dilakukan secara sengaja atau tidak sengaja dan tidak ada batasan pada bentuk pola komunikasi verbalnya, tetap dalam hal ekspresi wajah, sebuah lukisan, seni serta dalam teknologi. Kamunikasi tidak hanya digunakan untuk bertegur sapa atau sekedar hanya berbincang, komunikasi juga dapat digunakan sebagai alat atau media dalam penyampaian pesan dan makna dalam agama, budaya, ekonomi dan lain sebagainya. Seperti fenomena yang terjadi di Desa Kalisat, yang mana komunikasi 
itu sendiri mereka gunakan guna menunjang urusan ekonomi atau kegiatan jual-beli. Barang dan jasa yang mereka jual yaitu komodifikasi perkawinan.

Sedangkan opinion leader adalah suatu konsep atau bentuk yang tidak asing lagi bagi seseorang yang bergerak dalam bidang kehumasan. Seseorang dapat di katakan sebagai opinion leader apabila orang tersebut memiliki kharisma atau pengaruh bagi khlayak atau masyarakat ditempat mereka tinggal.

Opinion leader juga biasanya adalah seorang yang peka terhadap isu-isu yang berkembang di tengah lingkungan masyarakat. Singkat kata, seorang opinion leader adalah seorang yang berpengaruh cukup besar dalam lingkungan masyarakat. Bahkan tak jarang kegiatan apapun yang ada di dalam lingkungan atau segala informasi yang beredar di dalam lingkungan tersebut di pengaruhi oleh keberadan seorang opinion leader. Dalam kata lain, opinion leader adalah pusat dari segala informasi, yang akan di sambut baik oleh para masyarakat bahkan bisa jadi diterapkan dalam kehidupan sehari-harinya.

Penelitian ini bertujuan untuk mencari tahu bagaimana komodifikasi kawin kontrak di Desa Kalisat yang diungkap secara terstruktur dari pihak pihak yang terkait dalam praktik kawin kontrak di Desa Kalisat. Penelitian ini nantinya akan dikaji menggunakan teori komodifikasi Karl Marx yang mengkaji tentang nilai guna suatu pernikahan yang di kemas atau di komodifikasi menjadi nilai tukar yang mempunyai nilai jual.

\section{METODE PENELITIAN}

Metode penelitian ini menggunakan metode penelitian kualitatif, yang mana metode penelitian kualitatif menurut Creswell (2012: 4) ialah serangkain metode-metode yang digunakan untuk mengeksplorasi dan memahami suatu mak a yang dilakukan sejumlah individu atau suatu kelompok orang dan di anggap berasal sebab dari masalah sosial atau kemanusiaan. Pendekatan ini digunakan untuk menjelaskan bagaimana proses komunikasi yang dilakukan para opinion leader di desa Kalisat sehingga terjadinya suatu proses komodifikasi kawin kontrak di Desa Kalisat. Data yang didapatkan dari hasil observasi langsung serta wawancara kepada para informan, kemudian direduksi dan dianalisis, sehingga menjadi data yang sudah siap untuk disajikan. Data yang di sajikan terfokus kepada bagaimana proses komunikasi yang digunakan oleh opinion leader setempat, sehingga menimbulkan suatu bentuk komodifikasi kawin kontrak.

\section{HASIL DAN PEMBAHASAN}

\section{Komunikasi Opinion leader Dalam Komodifikasi Kawin Kontrak}

Komunikasi menurut Shannon dan Weaver (1949) yaitu suatu bentuk kegiatan interaksi yang digunakan oleh manusia yang saling mempengaruhi manusia lainnya, serta dilakukan secara sengaja atau tidak sengaja dan tidak ada batasan pada bentuk pola komunikasi verbalnya, tetap dalam hal ekspresi wajah, sebuah lukisan, seni serta dalam teknologi.

Dari hasil penelitian yang sudah peneliti lakukan, ditemukan suatu bentuk proses komunikasi yang terjadi di Desa Kalisat yaitu sebagai berikut Pertama-tama pelaku pria terlebih dahulu mendatangi makelar, yang mana tujuannya adalah untuk meminta informasi terkait kawin kontrak, serta bagaimana regulasi dan syarat untuk menikahi wanita atau gadis setempat. Dalam proses ini terjadilah suatu bentuk komunikasi, yang mana komunikasi ini dilakukan secara tatap muka atau face to face. Menurut Rakhmat (2009) komunikasi tatap muka (face to face) ialah salah satu cara interaksi atau komunikasi yang dilakukan antara seseorang dengan orang lain secara langsung (saling berhadapan). Dengan adanya proses komunikaasi secara tatap muka ini, feetback atau respon yang di berikan oleh komunikan kepada komunikator ini bersifat langsung serta memiliki pola komunikasi sirkular yaitu komunikasi akan berjalan dan bergulir terus menerus sehingga mencapai titik kesepakatan bersama. Hal ini dikarenakan adanya proses negosiasi antara pihak pelaku pria kepada para makelar terkait harga yang harus mereka bayar apabila ingin menikahi wanita setempat. Dalam proses inilah komodifikasi terjadi, para makelar ini mematok harga untuk masing-masing perempuan yang ingin dinikahinya berdasarkan spesifikasi yang sudah di tentukan oleh makelar sejak awal. Teknik yang di lakukan makelar untuk mengkomunikasikan atau menyakinkan kepada pihak perempuan ini bukan murni karna syariat agama, namun lebih kepada motif ekonomi. Hal ini terlihat dengan adanya mahar yang ditetapkan sang makelar kepada pelaku pria agar dapat menikahi perempuan yang di inginkannya, dengan berbagai macam harga sesuai dari kadar kecantikan, status perkawainan dan umurnya.

Sedangkan proses komunikaasi yang dilakukan makelar (komunikator) kepada calon mempelai wanita (komunikan) untuk terjun dalam praktik ini dengan menggunakan teknik komunikasi yang sifatnya mengajak dan membujuk dengan sejumlah keuntungan apabila pihak wanita ini mau di nikahkan secara kontrak teknik ini disebut sebagai teknik komunikasi persuasif yang mana menurut Purnawan (2002: 15) yaitu suatu kegiatan yang dilakukan seseorang untuk mempengaruhi orang lain atau membuat prilaku orang lain berubah sesuai dengan apa yang kita kehendaki dengan menggunakan komunikasi. Serta feetback dari hasil teknik komunikasi tersebut yaitu kesedian dari para pelaku wanita untuk mau ikut dinikahkan secara kontrak oleh seorang pria yang akan menikahinya. Dalam proses ini, terjadi kembali negosiasi untuk menentukan besaran mahar yang akan diterima oleh pihak wanita dari pihak pria, disinilah proses pola komunikasi sirkular berjalan, terjadi komunikasi berkelanjutan yang isinya membahas tentang negosiasi besaran mahar hingga menemui kesepakatan bersama. Dalam proses ini pun sama seperti proses sebelumnya, komunikasi yang dilakukan tidak melalui perantara media, namun komun- 
ikasi secara tatap muka atau face to face dan feedback terjadi secara langsung. Setelah pada tahap makelar selesai, selanjutnya calon mempelai pria dan wanita yang sudah setuju untuk melakukan praktik kawin kontrak ini diantar oleh makelar tersebut menuju ke opinion leader selanjutnya, yaitu kyai/mudin yang bertugas sebagai penghulu. Di tahap ini proses komunikasi serta komodifikasi masih tetap berjalan, hanya saja berbeda motif dengan proses pada makelar, yang mana makelar lebih menitik beratkan kepada motif ekonomi, sedangkan mudin atau penghulu ini lebih menitik beratkan kepada aspek agama. Para mudin/kyai setempat memberikan pernyataan atau petuah/wejangan kepada para pelaku kawin kontrak bahwa kawin kontrak ini sejatinya sama dengan kawin pada umumnya, karna kawin kontrak di desa Kalisat ini memenuhi unsur 4 syarat sah nikah, yaitu adanya walu nikah, adanya mempelai, adanya ijab \& qabul dan adanya saksi (setidaknya 2 orang), hanya saja yang membedakannya dari nikah pada umunya yaitu tempat pelaksanaanya saja, yaitu di rumah penghulu atau di rumah mempelai wanita. Masyarakat setempat yang sebagian besar sangat agamis, mereka sangat mempercayai betul apa yang dikatakan oleh mudin setempat terutama yang bersangkutan dengan agama. Disini lah peran kyai/mudin berpengaruh soal diterima atau tidaknya praktik kawin kontrak ini di kalangan masyarakat.

"Untuk masalah proses pernikahannya, masyarakat disini berpatokan apa kata kyai/mudin nak. Karna beliau-beliau ini yang lebih menguasai ilmu agama dan deket dengan Tuhan Yang Maha Esa, karna setiap hari beliau-beliau ini selalu mengamalkan nilai-nilai agama dan hampir setiap harinya selalu mengerjakan baik yang sunnah ataupun wajib". (wawancara dengan mbah min di warung kopi, tanggal 11 juli 2020).

Dalam hal ini, pernyataan para tokoh agama tentang diperbolehkannya kawin kontrak di Desa Kalisat membuat para pelaku semakin kekeh dalam menjalani kawin kontrak, bahkan ada yang melakukan praktik ini hingga berulangulang kali. Keyakinan ini juga datang dari pelaku laki-laki. Pelaku laki-laki semakin mantab untuk menjalani praktik kawin kontrak ini, karna adanya dukungan dari beberapa pihak, termasuk tokoh agama dan kepala desa serta perangkat desa setempat. Dalam tahap ini, pola komunikasi yang terjadi yaitu pola komunikasi linear, berbeda dengan sebelumnya yaitu pola komunikasi sirkular dan bersifat mengajak. Yang mana pola komunikasi linear ini adalah pola komunikasi satu arah yang dilakukan oleh komunikator yaitu mudin kepada komunikan yaitu pelaku kawin kontrak baik pria maupun wanita yang dilakukan dengan tatap muka. Bentuk komunikasi yang diberikan para mudin ini bersifat petuah atau wejangan, guna memantabkan hati dari kedua calon pelaku kawin kontrak ini.

Selain dari kedua peran di atas, ada juga peran dari kepala desa dan aparat desa setempat yang membuat proses kawin kontrak ini masih berjalan hingga saat ini. Karna syarat untuk menang dalam pemilihan kepala desa Desa Kalisat, seorang kepala desa harus mendukung adanya proses kawin kontrak ini, dan apabila ada calon yang tidak mendukung adanya praktik ini, maka dapat dipastikan calon tersebut minim mendapatkan dukungan. Itu lah sebabnya mengapa calon kepala desa yang mendukung kawin kontrak ini akan mendapat suara banyak bahkan menang dalam pemilihan kepala desa setempat. Hal ini disebut oleh Dharma (2018) sebagai konstruksi realitas social, karena telah terjadi pembentukan realitas di masyarakat bahwa kawin kontrak yang sebenarnya tidak benar secara agama dan norma, telah diubah menjadi sebuah keniscayaan di Kalisat.

\section{Komodifikasi dalam Kawin Kontrak di Kalisat}

Komodifikasi menurut Karl Marx yaitu bahwa apapun yang dapat diproduksi dan dapat diperjual-belikan, tidak mempunyai nilai guna murni yang dihasilkan, namun hanya mempunyai nilai jual. Hal itu diperjual - belikan bukan hanya untuk di gunakan saja. Komodifikasi menjelaskan proses dimana segala jenis yang tidak mempunyai nilai ekonomis lalu di beri nilai dan karenanya bagaiamana nilai tukar dapat menggantikan nilai-nilai social yang lain. Sebagai komoditas, barang atau jasa tersebut tidak hanya untuk digunakan tetapi memiliki daya jual. Asal kata komodifikasi berawal dari kata komoditi yang artinya barang atau jasa yang mempunyia nilai tukar ekonomi yang berarti perubahan fungsi atau bentuk sesuatu. Jadi, dapat di artikan bahwa komodfikasi berarti produk-produk sebagai komoditas yang bertujuan guna di perdagangkan atau pengubahan sesuatu menjadi komoditas (barang yang bisa ditukar) yang bisa diperjual-belikan sehingga menjadi lahan komersilisasi oleh beberapa pihak. Komersialisasi sendiri menurut (McManus dalam Didik Haryanto, 2018: 77-86) bahwa komersialisasi di sebutkan sebagai suatu bentuk kegiatan guna membuat atau mengubah sesuatu menjadi mempunyai nilai bisnis.

Hal ini terjadi pada fenomena perkawinan yang ada di Desa Kalisat, Kecamatan Rembang, Kabupaten Pasuruan, yang mana pernikahan adalah suatu kegiatan yang syarat akan nilai guna murni, diubah menjadi suatu pernikahan yang mempunyai nihai jual di pasaran. Proses komodifikasi ini dapat dilihat dari awal sejarahnya, yang mana awal sejarahnya mereka mengenal bukan kawin kontrak, mereka mengenalnya sebagai pernikahan pada umumnya.

Mereka sengaja menikahkan para perempuan setempat kepada para pendakwah yang datang ke desa mereka berkat rasa terimakasih kepada pendakwah tersebut karna sudah mau mengajarkan agama islam di lingkungan tempat mereka tinggal serta mereka beranggapan bahwa orang Arab merupakan keturunan langsung dari para Nabi, khususnya Nabi Muhammad SAW, tanpa berniat meminta sejumlah imbalan. Namun seiring berkembangnya jaman dan berubahnya pola hidup. Mereka mulai membuka jalur pernikahan untuk orang jawa yang ingin melakukan pernikahan dengan wanita sekitar dengan syarata adanya imbalan untuk segenap pelaku yang ikut terjun di dalamnya serta menutup pintu bagi para orang Arab yang tidak mau memberikan imbalan kepada mereka yang ikut terjun dalam praktik ini. 
Semakin berkembangnya jaman semakin terlihat bentuk komodifikasi ini, yaitu dengan adanya patokan harga yang ditetapkan oleh para makelar kawin kontrak kepada para pelaku kawin kontrak pihak laki-laki untuk para wanita atau gadis yang ingin mereka nikahinya secara kontrak. Yang mulanya imbalan tersebut bersifat sukarela tidak ditetapkan besaran maharnya. Besaran maharnya pun berbeda berdasarkan beberapa aspek seperti usia, kadar kcantikan serta status perkawinannya. Harga yang ditetapkan mulai dari 16 juta hingga 35 juta.

"Sekarang maharnya beda-beda mas, tergantung dari kadar kecantikan dan status perkawinan perempuannya. Hampir setiap tahun tarifnya meningkat, yaa karna setiap tahun kebutuhan juga naik mas. Kan yang ikut berperan juga banyak, enggak cuma ".mempelai wanita, ada jasa pengamanan dan lain-lain juga sih mas". (wawancara dengan cak bejo mantan makelar, tanggal 11 juli 2020, di warung kopi sekitar desa Kalisat).

Selain komodifikasi dari makelar, komodifikasi dari pihak pelaku wanita terhadap proses perkawinan ini pun dapat diliihat dari besaran mahar yang mereka minta kepada calon suami kontrakannya, yang awalnya mereka hanya meminta juki atau mesin jahit, kini mereka meminta sejumlah uang tunai sebagai maharnya.

"Dulu awalnya mahar yang kami minta itu sebuah mesin juki mas atau mesin jahit lah modelnya, karna mayoritas dari kami punya ke ahlian menjahit mas. Tapi sekarang karna jaman sudah modern dan apa apa mahal, besaranya mahar tergantung dari calon mempelai wanitanya." (Dinda "nama samaran" pelaku kawin taqliq, tanggal 13 juli 2020, di masjid desa Kalisat).

Selain dari segi ekonomi, kegiatan kawin kontrak ini dimanfaatkan oleh para calon kepala desa untuk menguatkan posisi kekuasaannya dari segi politik. Mereka yang mendukung adanya praktik ini dan tidak melarang keberadaanya di Desa Kalisat, akan medapatkan suara jauh lebih banyak dari calon kepala desa yang tidak menghendaki adanya kegiatan praktik terlarang ini

Dalam proses komodifikasi, terjadi komunikasi antara calon mempelai pria dengan makelar untuk mencari perempuan sebagai calon istri kontrak dan menegosiasikan harga. Setelah itu makelar melakukan komunikasi dengan calon istri kontrak dan terdapat proses negosiasi harga diantara keduanya. Komunikasi yang dilakukan ketiganya adalah komunikasi sirkular, yang mana pola komunikasi skirkular menurut (Djamarah: 2004), kata sirkular secara harfiah berarti bulat, bundar, atau keliling. Dalam proses sirkular itu terjadinya feedback atau umpan balik, yaitu terjadinya arus dari komunikan ke komunikator, sebagai penentu utama keberhasilan komunikasi. Bentuk kesepakatannya itu sendiri yaitu berupa harga atau mahar kawin kontrak.

Setelah menemui kesepakatan bersama, kemudian diba- wa ke kyai/modin untuk proses perkawinan secara kontrak. Proses komunikasi yang terjadi pada tahap ini yaitu komunikasi linear. Yang mana pola komunikasi linear ini adalah pola komunikasi satu arah yang dilakukan oleh komunikator yaitu mudin kepada komunikan yaitu pelaku kawin kontrak baik pria maupun wanita yang dilakukan dengan tatap muka. Bentuk komunikasi yang diberikan para mudin ini bersifat petuah atau wejangan, guna memantabkan hati dari kedua calon pelaku kawin kontrak ini, karna mereka percaya dan menuruti apa yang di katakan kyai/modin setempat, karna kepatuhan mereka kepada tokoh agama.

Dalam menjalankan aksinya, para opinion leader ini sudah memiliki jaringan tersembunyai yang tersebar di seluruh Pasuruan. Di Desa Kalisat sendiri para makelarnya dinaungi oleh organisasi yang dipimpin oleh Cak Bagong (nama samaran). Serta peran kepala desa yang memperbolehkan adanya praktik ini. Karna siapapun orang yang tidak pro terhadap praktik ini, maka sudah dipastikan pada saat pemilihan kepala desa, orang tersebut minim mendapatkan dukungan atau bahkan tidak ada yang memilihnya. Peran aparat desa disini bisa dikatakan sebagai pihak keamanan, yang menjamin keberlangsungan kegiatan kawin kontrak dengan tidak mengeluarkan larangan ataupun aturan yang mengatur tentang praktik kawin kontrak di Desa Kalisat ini.

Dalam melaksanakan aksinya, opinion leader setempat mengunakan teknik komunikasi secara persuasif, yang mana seorang opinion leader merubah pandangan atau persepsi warga sekitar tentang nilai moral dari pernikahan sehingga itu sendiri mejadi pernikahan yang memiliki nilai jual, salah satu contohnya yaitu dari segi ekonomi. Para pelaku wanita akan dijanjikan sejumlah harta dari calon pelaku pria guna meningkatkan stratus ekonomi mereka. Hal ini dapat dilihat dari adanya variasi mahar yang ditetapkan oleh para pelaku kawin kontrak ini kepada laki-laki hidung belang yang ingin mencari wanita untuk di jadikan istri kontrakanya. Mahar yang sudah ditetapkan itu nantinya akan di bagi secara merata kepada setiap pelaku yang ikut terlibat dalam praktik ini, termasuk kepada mempelai wanitanya. Serta memakai contoh pelaku-pelaku terdahulu yang bisa membuka usaha seperti contohnya toko sembako atau lainya dari hasil nafkah yang di berikan dari suami taqliqnya yang dikumpulkan lalu di tabung. Walaupun kenyataannya tidak semua pelaku mendapat keberuntungan secara finansial dari praktik ini. Dalam kasus ini, opinion leader yang ada di Desa Kalisat ini bersifat pasif, karna pelaku praktik kawin kontrak dalam kasus ini dari pihak laki-laki yang datang menemui opinion leader ini untuk melaksanakan pernikahan dan meminta wejangan/petunjuk kepada beliau. Serta opinion leader (makelar, kyai/mudin, aparat desa) mempunyai perannya masing-masing, yang mana para makelar tugasnya sebagai mempertemukan pria hidung belang dengan pria yang ingin menikahinya, kyai/mudin bertugas sebagai eksekutor perkawinannya atau penghulunya, lalu aparat desa bertugas sebagai pelindung/keamanan agar praktik ini dapat terus berjalan sebagaiaman mestinya.

Seperti apa yang sudah dijelaskan di atas, bahwa komodifikasi ialah suatu proses transformasi suatu barang dan 
jasa, yang semula dinilai karna syarat akan nilai gunanya, lalu diubah menjadi suatu barang dan jasa yang di minati karna mempunyai nilai jual di pasar (Dharma, 2018). Dampak nyata yang bisa dilihat berkat dari fenomena komodifikasi bagi pelaku pihak wanita kawin kontrak di Desa Kalisat yaitu:

1. Dengan adanaya proses komodifikasi ini, pernikahan yang awalnya yaitu suatu kegiatan yang dinilai karna syarat akan nilai gunanya, kini di Desa Kalisat melihat suatu perkawinan ini mempunyai nilai jual di pasaran, contohnya pernikahan yang hakikatnya adalah suatu proses yang dilakukan sekali seumur hidup, kini dimanfaatkan sebagai suatu kegiatan yang dapat mendatangkan keuntunan bagai berbagai pihak yang ikut andil dalam proses ini. Seperti contohnya, sebagai wadah guna pemuas nafsu serta sebagai sumber pendapatan dalam hal perekonomian guna meningkatkan derajat ekonomi pelakunya. Contohnya yaitu, Keuntungan yang di dapat para makelar kawin kontrak di Desa Kalisat ini bisa mencapai hingga 50\% dari harga yang sudah ditetapkan para makelar calon pelaku kawin kontrak pria kepada calon mempelai wanita kontrakannya. Pendapatan tersebut jauh melebihi pendapatan apabila mereka menjadi seorang buruh tani atau tukang ojek di kala tidak ada customer.

2. Pelaku wanita kawin kontrak yang pada awalnya berprofesi sebagai buruh tani atau buruh cuci, setelah melakukan praktik kawin kontrak berhasil mempunyai toko sembako sendiri, setelah uang yang diberikan suami sirinya itu ditabung.

3. Keuntungan yang lain yaitu bagi para calon Kepala Desa yang ingin mencalonkan dirinya menjadi Kepala Desa sekitar, dengan cara memperlihatkan dirinya jika mereka mendukung adanya komodifikasi praktik kawin kontrak ini, maka bisa di pastikan mereka akan mendapatkan suara jauh lebih banyak dari pada mereka para calon Kepala Desa yang menunjukan sikap tidak kesetujuan mereka terhadap praktik kawin kontrak ini.

\section{KESIMPULAN}

Opinion leader di Desa Kalisat menggunakan pola komunikasi sirkular (untuk makelar) serta menggunakan teknik komunikasi persuasif guna mengajak pelaku kawin kontrak untuk ikut serta dalam praktik terlarang ini dengan di janjikan sejumlah keuntungan apabila mau ikut dalam praktik ini dan pola komunikasi linear (untuk kyai/modin). Fenomena komdodifikasi kawin kontrak dapat terjadi sebab adanya globalisasi, modernisaai serta kemajuan-kemajuan lain yang bersangkutan dengan ekonomi, yang memaksa pelakunya terus beradaptasi dengan perubahan yang ada demi bertahan hidup. Selain karna kebutuhan untuk bertahan hidup, komodifikasi juga dapat terjadi karna tuntutan gaya hidup yang di sebabkan oleh era globalisasi, serta kenginan dari pelaku yang ingin hidup mewah. Bergesernya pola hidup juga bertambahnya biaya hidup. Hal ini menjadi salah satu f- aktor adanya komodifikasi dalam hal perkawinan di desa Kalisat, Kecamatan Rembang, Kabupaten Pasuruan. Dampak nyata yang bisa dilihat dari fenomena komodifikasi kawin kontrak ini yaitu adanya patokan harga untuk calon mempelai wanita yang ditetapkan oleh para makelar serta tuntutan mahar yang di minta oleh pihak wanita yang awalnya hanya mesin jahit kita berupa sejumlah uang tunai yang besarannya tergantung kesepakatan bersama.

\section{UCAPAN TERIMAKASIH}

Terima kasih kami ucapkan kepada semua pihak yang telah membantu terciptanya karya ilmiah ini, terutama pengelolah Jurnal KANAL yang telah memberikan kesempatan untuk penerbitan karya ilmiah ini.

\section{REFERENSI}

Creswell, John W. (2012). Research Design Pendekatan Kualitatif,. Kuantitatif, dan Mixed. Yogyakarta: Pustaka Pelajar.

Dharma, F A. (2018). Konstruksi Realitas Sosial: Pemikiran Peter L. Berger Tentang Kenyataan Sosial. Kanal: Jurnal Ilmu Komunikasi, 7 (1), 1-9.

Dharma, F. A. (2018) Komodifikasi Folklor dan Konsumsi Pariwisata di Indonesia. BioKultur, VIII(1), 1-115.

Djamarah, Bahri Syaiful. (2004). Pola Komunikasi Orang Tua \& Anak Dalam keluarga. Jakarta: PT. Reneka Cipta.

Fitriany, A., \& Fajriyah, I. (2015). Sejarah Budaya Kawin Sirri di Desa Kalisat Kecamatan Rembang Kabupaten Pasuruan. Jurnal Edukasi, 1(2), 253-274.

Haditz Riwayat Muslim No. 1406.

Hariyanto, D. (2018). Commodification of Umrah Workship in Capitalism Umrah Travel in Indonesia. OSR Journal Of Umanities And Social Science IOSRJHSS. Vol. 23. e-ISSN: 2279-0837, p-ISSN: 2279-0845. Pages: 77-86.

Purnawan, E. A. 2002. Dynamic Persuasion. Jakarta: Penerbit Gramedia.

Rakhmat, Jalaludin. (2009). Psikologi Komunikasi, Bandung: PT. Remaja. Rosdakarya.

Shannon, C. and W. Weaver. (1949). The Mathematical Theory of Communication. Beverly Hills.

Conflict of Interest Statement: The authors declare that the research was conducted in the absence of any commercial or financial relationships that could be construed as a potential conflict of interest.

Copyright (C) 2021 Hariyanto and Difa This is an open-access article distributed under the terms of the Creative Commons Attribution License (CC BY). The use, distribution or reproduction in other forums is permitted, provided the original author(s) and the copyright owner(s) are credited and that the original publication in this journal is cited, in accordance with accepted academic practice. No use, distribution or reproduction is permitted which does not comply with these terms. 